\title{
TEKNIIKAN FILOSOFIAN KALEIDOSKOOPPI
}

\author{
AIRAKSINEN TIMO (2003) \\ Tekniikan suuret kertomuk- \\ set. Filosofinen raportti. \\ Otava, 399 sivua.
}

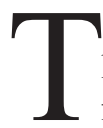

imo Airaksinen käsittelee kirjassaan tekniikanfilosofiaa. Hän lähtee

liikkeelle teknopessimismin ja optimismin ajatusmaailmoista, tarkastelee tekniikan determinismiä, imperatiivia ja autonomiaa. Teoksen kohde on vaativa, varsinkin, kun Airaksinen heti aluksi toteaa, että tekniikan filosofiasta on kirjoitettu paljon, mutta tekniikan filosofiasta ei ole kehittynyt oppirakennelmaa samassa mielessä kuin esimerkiksi tieteenfilosofiasta. Ei ole olemassa myöskään tekniikan tiedettä, johon termi "teknologia" etymologisessa merkityksessään saattaisi viitata.

Mutta tekniikkaa on ja se vaikuttaa meidän kulttuuriimme ja jokapäiväiseen elämäämme. Tekniikka itsessään on eräässä mielessä mykkää ja tekniikan spesialistien halua ja kykyä kirjoittaa tekniikasta on usein stereotyyppisesti pidetty hyvin rajallisena. Siksi tekniikasta kirjoittaa tässäkin tekniikasta kiinnostunut filosofi, ei filosofiasta kiinnostunut "teknikko" tai insinööri.

Teos on kaleidoskooppimai- nen, kuten Airaksinen itsekin toteaa. Kun tähän kaleidoskooppiin katsoo, näkee erilaisia asioita riippuen siitä, minkälaisessa valaistuksessa siihen tarttuu ja miten kaleidoskooppia kääntelee. Airaksisen kaleidoskooppi on lisäksi melko massiivinen, ei niinkään materiaalin painavuuden kuin sen määrän vuoksi. Kaleidoskoopin helmiä on paljon ja ne säihkyvät kauniisti, mutta yksittäisten helmien erottaminen on usein vaikeaa.

Teoksen tarkastelutapa ei ole systemaattinen tai tekninen, mikä aiheen kannalta olisi luontevaa. Kirjan alaotsikkokin $\mathrm{Fi}$ losofinen raportti lienee viisainta ymmärtää ironiaksi: Airaksinen kyllä kertoo esipuheessa todella tehneensä paljon tutkimusta Japanissa Tokiossa Tokyo Institute of Technologyssa (TiTech) lukuvuonna 1999-2000. Mutta jos lukija odottaa raporttia, jossa kerrotaan, mitkä olivat tutkimuksen tavoitteet, ongelmat, tutkimusmenetelmät ja tulokset, joutuu pettymään. Voi olla, että Airaksinen ymmärtää filosofisen tutkimuksen tässä kirjassa esittämällään tavalla, mutta lukijalle sen antama kuva filosofiasta on kovin kapea.

Airaksisen tyyli on helposti luettavaa, mutta enemmän jutustelevaa kuin tiiviisti etenevää argumentointia tai retorisesti kiinteää esseistiikkaa. Aiheesta siirrytään sujuvasti toiseen. Tämä pitää kiinnostuksen yllä, mutta jo hetken päästä huomaa olevansa toisessa aiheessa, eikä edellisestä aiheesta ole enää selkää muistikuvaa. Airaksinen puolustelee omaa tekstiään usealla tavalla: vetoamalla filosofisen tekstin vaikeuteen ("Filosofinen teksti ei aina ole helppoa...") ja lukijan laiskuuteen (...ja argumentaatioon perehtymisessä on oma työnsä.) Joutuupa lukija (tietenkin) myös arvioimaan oman oppineisuutensa, koska kirjassa käytetään paljon termejä, jotka eivät ole arkikielestämme tuttuja, vaan edellyttävät etiikan perusteiden tuntemusta.

\section{ESIMERKIT VALAISEVAT AJATUKSENJUOKSUA}

Epäilemättä Airaksisen kirja on tärkeä: se käsittelee äärimmäisen tärkeitä asioita koko länsimaisen kulttuurin ja meidän jokapäiväisen elämämme kannalta, se antaa ajattelulle virikkeitä ja sen esittämät ajatuskulut ovat riittävän epämääräisiä. Airaksisen esitystapa on lisäksi sen verran itsekeskeinen ja subjektiivinen, että hänen kaikkia 
ajatuksiaan ei tarvitse ottaa aina kovin vakavasti. Näin lukijalle ei tule vaikutelmaa, että mestariajattelija olisi miettinyt asiat valmiiksi. Parhaimmillaan Airaksinen onkin silloin, kun hän esittää valaisevia esimerkkejä tekniikan ja arkielämämme yhteyksistä tai pikku nokkeluuksia teeman tiimoilta tyyliin: "Mitä Jumala ei pysty tekemään? Hän ei pysty valmistaan viiden euron seteliä. Miksi ei? Siksi että tuo seteli olisi väärennös, oli sen tehnyt Jumala ta Kalle Kehveli. Vain EU voi laskea liikkeelle euroissa arvotettuja seteleitä. Esimerkki osoittaa kuinka sopimukset, tässä tapauksessa demokraattinen perustuslaki, luovat ihmisen maailmaa, yhteiskuntaa ja sen osasia." (mt., 54)

Airaksisen metodina on esimerkein osoittaa erilaisia asioita. Tämä on havainnollista ja houkuttaa usein hyväksymään kirjoittajan näkemykset. Ongelmalliseksi tämän tavan tekee se, että siinä väitetään kovin paljon koko yhteiskunnallisen tai kulttuurisen ajattelutavan luonteesta, siis siitä, mitä voimme väittää yhteiskunnan kehityksestä. Otan yhden esimerkin.

Airaksinen väittää "Kun nostaa broilerin kaupan pakastealtaasta, on aivan sama, minkä niistä ostaa, sillä kaikki ovat teollisen tuotteen tapaan samanlaisia eli saman standardin alaisia.”(Airaksinen, 169). Tämä on esimerkki siitä, miten teknisten laitteiden tuottama tuotelaji muuttaa maailmaa. Ennen vanhaan, kun ihminen valmisti esineen, sen yksilöllisyys oli otettava huomioon käytössä. Kun tekniikka valmistaa tuotteen, sen yksilöllisyyttä ei ole tarkoitus ottaa huomioon. Takuu on sitä varten, että virheellisen tuotteen saa vaihdetuksi kelvolliseen. Koska näin on, kuluttaja ei kiinnitäkään enää huomiotaan yksilöllisen tuotteen erityisiin ominaisuuksiin, vaan itse tuotemerkkiin: broilerit ovat saman valmistajan tuotteina standardisoituja, mutta eri tuotemerkeillä on eroa. Siksi voimme sujuvasti puhua siitä, että jokin polkupyörämerkki tai automerkki on hieno, hyvä ja haluttavampi kuin jokin toinen. Tätä ilmiötä Airaksinen kutsuu arvojen teknodeterminismiksi. Tekniikka irtautuu tekemisen taidosta ja sen tyylistä.

Esimerkki broilerin tuottamisen ja kuluttamisen suhteesta on esimerkki siitä, miten tekniikka määrää ihmisen elämää sisäisesti ja ulkoisesti. Airaksinen on kyllä varautunut vasta-argumentteihin. Esimerkki on toki rajallinen, mutta Airaksisen mukaan "suppeiden esimerkkien pitäisi riittää teknodeterminismin hyväksymiseen, sillä mitään muuta näyttöä ei ole tulossa johtuen yhteiskunta-ajattelun luonteesta.” (mt., 169) Tästä Airaksisen laajentaa: "Kyse on kuitenkin kertomuksesta ja subjektiivisen havainnon fenomenologiasta. Näin ajatellen voi sanoa, että teknodeterminismi on esimerkein kuviteltavissa oleva merkityksellinen tarina, ja sellaisena sen voi myös hyväksyä."

Eli idea on suurinpiirtein sellainen, että paras tarina voittaa ja siihen on tyytyminen. Kertomuksen uskottavuus taas riippuu, sen lisäksi mitä siinä kerrotaan, myös siitä, kuka kertoo, miten kerrotaan ja kuka kertomusta kuuntelee ja minkälaisessa tilanteessa. Kummitusjutun uskottavuus (esimerkiksi postmoderni tekniikan demonisoiminen) on hyvin tilannesidonnai- nen ja siksi myös tarinat tekniikasta ovat sidoksissa kuulijan teknologiakontekstiin. Airaksinen on hyvä tarinankertoja. Tarinoiden uskottavuus perustuu kuitenkin myös siihen, minkälaisin faktoin tarinaa tuetaan, kuinka selkeä on tarinan rakenne ja minkälaisiin käsitteellisiin ratkaisuihin se tukeutuu. Airaksista lukiessa ei aina ole kovin vakuuttunut tarinan uskottavuudesta, mutta aina ei ole kovin huolissaan siitä: tarinat alkavat muuttua taruiksi.

\section{TEKNIIKKA: TAITOA TEHDÄ JA KÄYTTÄÄ}

Airaksisen tapa kirjoittaa ja argumentoida on hyvin retorinen. Hän käsittelee mielenkiintoisella tavalla esimerkiksi tekniikkatermin kahta erilaista merkitystä - taitoa tehdä ja taitoa käyttää. Laulutekniikka tai halkojen hakkaamisen hyvä tekniikka ovat esimerkkejä ensimmäisestä, laulun äänenvahvistustekniikka (mikrofoni, vahvistin jne.) taas esimerkki jälkimmäisestä. Airaksinen siis tekee käsiteanalyysia, mutta hän ei halua kutsua sitä sellaiseksi. Airaksinen kirjoittaa: "Olisi hauska olla välittämättä ja vain puhua, tuottaa tekstiä vailla vastuuta sen merkityksestä, nojata ilmeiseen ja tukea sitä, mikä on tuttua. Eräistä asioista on silti muistutettava, eikä muistutus ole yhtä pahaa ja vastenmielistä kuin merkitysanalyysi. Muistutettakoon siis seuraavista totuuksista." (161)

Tähän voisi tosikkomaisesti todeta: mitä pahaa ja vastenmielistä on merkitysanalyysissa ja muuttuuko se vähemmän vastenmieliseksi ja pahaksi, jos sitä kutsutaan muistuttamiseksi? Mitä ovat "totuudet", joihin Airaksinen vetoaa? Retorisia 
suostuttelevia keinoja vastuuttomalta tekstintuottajalta?

\section{TEKNIKKA, SEN MERKITYS JA ASEMA KULTTUURISSAMME}

Esipuheessa Airaksinen viittaa tärkeään asiaan: sanojen teknologia, tekniikka ja tiede väliseen suhteeseen. Hän suosittaa, että teknologia-sanan tilalla käyttäisimme aina sanaa tekniikka, kun se on mahdollista, ja teknologiaa vain silloin, kun se on erityisistä syistä perusteltua. Teknologia viittaisi silloin "kaiken tekniikan järjestelmään". Tekniikka taas erillisiin laitteisiin, niiden toimintaan ja laitteiden kokoelmiin järjestelmissä.

Tärkeä on myös huomata, että usein käytetty ajatuskulku siitä, että tekniikka on sovellet- tua tiedettä, ei ole pitävä. Historiassa monet tekniikat ovat kehittyneet tieteestä riippumatta (usein jo ennen kuin tiedettä on ollut olemassa) ja myös nykytekniikan kehitys suhteessa tieteeseen on monimuotoinen. Airaksisen tarkastelut Japanin teknisen kehitystyön suhteesta tieteellisen perustutkimuksen suhteellisen vaatimattomiin tuloksiin on kiinnostava. Tieteellinen tutkimus, sovellettu tieteellinen kehittämistyö, tutkimus ja kehitystoiminta voidaan liittää yhteen, mutta samalla ne voivat kulkea omia polkujaan tuloksellisesti ainakin joitakin aikoja ja paikallisesti kehittyen. Airaksista voi suositella itserefleksion välineeksi ja ymmärryksen lisääjänä: lukija voi miettiä omia tarinoitaan tekniikasta ja huomata, miten eri tavoin asioita voidaan suhteuttaa toisiinsa. Toivottavasti se toimii innoittajana systemaattiselle tarkastelulle, ei vain filosofeille, vaan myös tekniikan parissa toimiville insinööreille. Ehkä he voisivat antaa äänen mykälle tekniikalle.

Itselleni kävi niin, että mitä tarkemmin yritin Airaksisen tekstiä lukea, sitä enemmän asia hukkui retoristen keinojen alle. Mitä enemmän yritän siitä kirjoittaa, sitä enemmän peittyy itse asia: tekniikka, sen merkitys ja asema kulttuurissamme ja arjen elämässä. On siis aika lopettaa "vastuuton tekstin tuottaminen".

Pekka Kalli 